\title{
Perlindungan Hukum terhadap Anak Sebagai Korban Kekerasan yang Terjadi di Sekolah
}

\author{
Felda Rizki Azalia \\ Magister Hukum Universitas Indonesia \\ Correspondence email: feldarizkiazalia@yahoo.com
}

\begin{abstract}
Abstrak. Tindak kekerasan yang dialami oleh anak khususnya di sekolah menjadi perhatian oleh Komisi Perlindungan Anak Indonesia. Hal ini menjadi latar belakang perlu ditinjau jauh tentang perlindungan hukum yang diterima oleh anak sebagai korban kekerasan disekolah, sebagaimana kita tahu bahwa sekolah itu adalah tempat mendidik anak agar menjadi manusia yang berpendidikan. Peran seorang guru adalah sebagai orangtua disekolah, seharusnya memberikan pendidikan dan pembelajaran yang pantas, bukan menjadi oknum terhadap kekerasan terhadap siswa disekolah. Fokus permasalahan yang akan dibahas yaitu pertama, apa saja faktor yang menyebabkan tingginya tindakan kekerasan terhadap anak di sekolah yang terjadi di Indonesia saat ini dan kedua bagaimana tindakan yang dilakukan oleh KPAI dan Pemerintah dalam mengatasi permasalahan kekerasan terhadap di sekolah seperti yang terjadi di Indonesia saat ini. Tulisan ini menggunakan metode penelitian yang digunakan adalah penelitian hukum normatif yang menggunakan metode pengumpulan bahan hukum adalah studi kepustakaan atau studi dokumen (documentary study). Hasil yang diharapkan pada penelitian ini adalah memberikan imbauan terhadap guru, orangtua dan siswa agar sekolah perlu turut terlibat dalam pengawasan anak didiknya dan melaksanakan beberapa peran yang bisa diambil sekolah untuk melindungi anak atau siswanya dengan menjalankan kembali fungsi guru sebagai tenaga pendidik yang bermoral dan bertakwa kepada Tuhan Yang Maha Esa, memberikan motivasi dan semangat terutama dari orangtua dirumah untuk mengajarkan anak berpikir positif tentang kekerasan yang telah terjadi kepadanya.
\end{abstract}

Kata Kunci: Perlindungan Hukum, Kekerasan Anak, Sekolah

\begin{abstract}
Acts of violence experienced by children, especially in schools are of concern to the Indonesian Child Protection Commission. This becomes the background that needs to be reviewed further about the legal protection received by children as victims of school violence, as we know that the school is a place to educate children to become educated human beings. The role of a teacher is as a parent in school, should provide appropriate education and learning, not to be a person against violence against students at school. The focus of the problem that will be discussed is first, what are the factors that cause high acts of violence against children in schools that occur in Indonesia at this time and second how the actions taken by KPAI and the Government in overcoming problems of violence against schools like what is happening in Indonesia today. This paper uses the research method used is normative legal research that uses the method of gathering legal material is a literature study or documentary study. The expected outcome of this research is to give an appeal to teachers, parents and students so that schools need to be involved in the supervision of their students and carry out some roles that schools can take to protect their children or students by resuming the teacher's function as a moral educator and devoted to God Almighty, provides motivation and enthusiasm, especially from parents at home to teach children to think positively about the violence that has happened to him.
\end{abstract}

Keyword: Legal Protection, Child Violence, Schools

\section{PENDAHULUAN}

Anak adalah amanah dan sekaligus karunia terbesar dari Tuhan Yang Maha Esa, oleh karena itu anak harus dijaga karena di dalam dirinya melekat harkat, martabat serta hak-hak sebagi manusia yang harus dijunjung tinggi. Selain itu anak merupakan generasi penerus bangsa sekaligus penerus cita-cita perjuangan bangsa serta sumber daya manusia untuk pembangunan nasional. Tentunya hak-hak yang dimiliki oleh anak merupakan hak asasi manusia yang telah diamanatkan dalam Undang Undang Dasar Negara Republik Indonesia Tahun 1945 serta Konvensi Perserikatan Bangsa-Bangsa tentang hak anak. Setiap anak berhak atas kelangsungan hidup, tumbuh dan berkembang, berpartisipasi serta berhak atas perlindungan dari tindak kekerasan dan diskriminasi serta hak sipil dan kebebasan. Orang tua, keluarga, dan masyarakat bertanggung jawab untuk menjaga dan memelihara hak asasi tersebut sesuai dengan kewajiban yang dibebankan oleh hukum. Dengan adanya perlindungan hak anak, keberadaan anak yang menjadi tanggung jawab bangsa diharapkan dapat menyongsong masa depan secara baik dalam kehidupan di lingkungan keluarga maupun di lingkungan masyarakat. Demikian pula dalam rangka penyelenggaraan perlindungan anak, negara dan pemerintah bertanggung jawab menyediakan fasilitas dan aksesibilitas bagi anak, terutama dalam menjamin pertumbuhan dan perkembangannya secara optimal dan terarah. ${ }^{1}$

${ }^{1}$ Benedhicta Desca Prita Octalina, Perlindungan Hukum Terhadap Anak Korban Eksploitasi Ekonomi, Jurnal Skripsi Peradilan dan Penyelesaian Sengketa Hukum, 2014, hal. 1-2. 
Undang Undang Dasar Negara Repbulik Indonesia 1945 telah mengamanatkan dalam Pasal 28B ayat (2) mengatur dengan tegas mengenai hak yang dinyatakan sebagai berikut, "Setiap anak berhak atas kelangsungan hidup, tumbuh, dan berkembang serta berhak atas perlindungan dari kekersan dan diskriminasi". Hal ini memberikan pernyataan bahwa anak memiliki hak yang dijamin oleh negara untuk dilindungi dalam hal-hal yang telah ditetapkan dalam konstitusi. Untuk selanjutnya dalam pelaksanaannya maka diatur lebih lanjut dalam Undang-Undang Nomor 35 Tahun 2014 tentang Perlindungan Anak pada Pasal 21 ayat (1) yang menyatakan,'Negara, Pemerintah, dan Pemerintah Daerah berkewajiban dan bertanggung jawab menghormati pemenuhan Hak Anak tanpa membedakan suku, agama, ras, golongan, jenis kelamin, etnik, budaya dan bahasa, status hukum, urutan kelahiran dan kondisi fisik dan/atau mental." Melalui pasal ini dapat diambil pemahaman bahwa negara dan pemerintah wajib terhadap penjaminan pemenuhan hak anak dan selanjutnya harus dirumuskan sebuah kebijakan dan pelaksanaan kebijakan dalam penyelenggaraan perlindungan anak. ${ }^{2}$

Hak-hak terhadap anak yang diatur dalam Undang Undang Perlindungan Anak didalam BAB III tentang Hak dan Kewajiban dari anak. Dimana setiap anak memiliki hak untuk hidup, tumbuh, berkembang dan berpartisipasi secara wajar sesuai dengan harkat dan martabat kemanusiaan, selain itu anak juga berhak untuk mendapatkan perlindungan dari kekerasan dan diskriminasi yang merupakan bunyi dari Pasal 4 Undang Undang Perlindungan Anak. ${ }^{3}$ Untuk mengembangkan diri dan tumbuh berkembang anak memiliki hak untuk mendapatkan pendidikan dan pengajaran dalam rangka pengembangan pribadinya dan tingkat kecerdasannya sesuai dengan minat dan bakatnya yang dituliskan dalam Pasal 9 Undang Undang Perlindungan Anak, hak ini merupakan turunan dari pelaksanaan dari Pasal 31 ayat (1) yang menyatakan,"Setiap warga negara berhak mendapat pendidikan". ${ }^{4} \mathrm{Hal}$ ini menjadi kunci bahwa anak juga memiliki hak atas pendidikan dan pengembangan dirinya disekolah. Anak memiliki hak untuk mendapatkan kenyamanan dalam menuntut ilmu di sekolah yang merupakan pernyataan tersirat dari konstitusi.

Sekolah merupakan bentuk sarana pendidikan yang diberikan oleh pemerintah. Seperti yang dijelaskan sebelumnya, bahwa pendidikan merupakan hak yang paling asasi yang dimiliki semua orang, dan yang paling dasar adalah pendidikan terhadap anak yang merupakan generasi penerus bangsa. Melalui pendidikan yang baik maka akan menciptakan sumber daya manusia yang memiliki kompetensi tinggi dalam menjawab era globalisasi yang penuh dengan tantangan dan kompetisi. Hak atas pendidikan ini merupakan salah satu yang menjadi pilar yang harus dipenuhi oleh negara karena pemenuhan terhadap pendidikan adalah salah satu indikator yang penting apakah negara itu negara maju atau negara berkembang, karena pendidikan adalah faktor utama penentu negara itu untuk maju dan berkembang dalam era globalisasi ini. ${ }^{5}$ Untuk menciptakan peserta didik yang cerdas ini, tentunya lingkungan pendidikan yang diciptakan disekolah harus sehat dan bebas dari kekerasan atau diskriminasi yang dapat menyebabkan psikologis anak menjadi terganggu dan menyebabkan anak menjadi tidak mau datang kesekolah karena adanya tindakan kekerasan yang dilakukan.

Bentuk kekerasan yang terjadi dalam dunia pendidikan akhir-akhir ini sangat banyak, padahal sekolah sebagai sarana pendidikan dan merupakan tempat untuk menuntut ilmu, mengembangkan potensi anak, dan harusnya menjadi tempat yang aman dan nyaman serta kondusif dari tindak kekerasan. Namun dalam kenyataannya saat ini banyak sekali ditemui kasus kekerasan yang terjadi disekolah. Tindakan kekerasan ini dilakukan dari kalangan siswa sendiri, orangtua siswa, pengurus sekolah bahkan guru yang harusnya adalah panutan dari anak-anak untuk memiliki moral yang baik malah melakukan tindakan kekerasan. Kekerasan yang terjadi di dunia pendidikan saat ini merupakan permasalahan terbesar yang dihadapi oleh bangsa dan negara ini. Di Indonesia saat ini sangat banyak terjadi kekerasan yang tempatnya adalah disekolah seperti kekerasan yang dilakukan oleh guru terjadi di Jagakarsa, Jakarta Selatan seorang guru memukul muridnya yang masih kelas $1 \mathrm{SD}$ dengan penggaris besi atau pelajar sendiri yang menjadi tersangka seperti kasus yang terjadi di jalan Daan Mogot, Cengkareng, Jakarta Barat seorang pelajar tewas disabet celurit saat tawuran diberitakan pada tahun 2013 lalu. ${ }^{6}$

Kasus lainnya yang baru-baru ini terjadi yaitu diduga orangtua siswa memukul dua orang siswa secara bergantian di dalam ruangan kelas. Menurut Komisi Perlindungan Anak Indonesia tindakan kekerasan ini sangat disayangkan terjadi karena jika benar pelaku adalah orang tua siswa, mengapa bisa masuk kedalam kelas pada saat proses belajar disekolah, namun terkait pelaku masih menjadi penyelidikan dari KPAI dan Kemendikbud dan diduga kejadian adalah di Pontianak yang masih terus diselidiki. ${ }^{7}$ Kasus kekerasan juga terjadi di Pangkal Pinang yang dilakukan oleh guru di Sekolah Menengah Pertama yang menganiaya murid dengan menampar 2 (dua) orang anak

${ }^{2}$ Indonesia, Undang Undang Perlindungan Anak, UU No. 35 Tahun 2014, LN No. 297 Tahun 2014, TLN No. 5606, Pasal 21.

${ }^{3}$ Ibid, Pasal 4.

${ }^{4}$ Indonesia, Undang Undang Dasar Negara Republik Indonesia Tahun 1945 Amandemen ke IV, Pasal 31 Ayat (1).

${ }^{5}$ A. Siti Hajar Rezki Irawan, "Pemenuhan Hak Konstitusional Terhadap Fakir Miskin dan Anak Terlantar Dalam Bidang Pendidikan Di Kota Makassar", Skripsi Universitas Hasanuddin, Makassar, 2013.

${ }^{6}$ Tri Lestari Utami, Kekerasan Dalam Dunia Pendidikan, Jurnal Ilmu Pendidikan, 2014, hal. 1.

${ }^{7}$ Moh. Nadlir, "Video Kekerasan terhadap Siswa, Pelaku Diduga Orangtua Siswa", Kompas, (6 November 2017). 
muridnya secara bergantian. ${ }^{8}$ Kasus di atas memberikan gambaran sangat miris terhadap pendidikan yang terjadi saat ini, dunia pendidikan yang harus menciptakan moral yang baik malah memberikan pengajaran buruk terhadap siswanya.

Berdasarkan data dari Ketua Komisi Perlindungan Anak Indonesia (KPAI) Asrorun Niam Sholeh menyayangkan kenaikan jumlah anak sebagai pelaku kekerasan atau bullying di sekolah sepanjang tahun 2015. Berdasarkan total kasus kekerasan di sekolah yang dihimpun, ada 79 kasus anak sebagai pelaku bullying dan 103 kasus dengan anak sebagai pelaku tawuran. Jumlah ini bertambah jika dibandingkan tahun 2014, di mana bullying ada 67 kasus dan tawuran ada 46 kasus. Kenaikan jumlah kasus tawuran termasuk yang cukup signifikan, yakni lebih dari 50 persen di tahun 2015 dibandingkan tahun 2014 lalu. Di sisi lain, kasus kekerasan yang menempatkan anak sebagai korban di sekolah justru berkurang di tahun ini. Jumlah anak sebagai korban kekerasan di sekolah tahun 2015 adalah 147 kasus, dengan total di tahun 2014 sebanyak 159 kasus. Sedangkan anak yang menjadi korban kasus tawuran ada 87 kasus, turun cukup banyak dari tahun 2014 dengan total 113 kasus tawuran. ${ }^{9}$

\section{Rumusan Masalah}

Beberapa kasus diatas menggambarkan sangat prihatinnya dunia pendidikan Indonesia saat ini yang sangat rentan dengan hal-hal kekerasan dan saat ini yang sedang trend yaitu kasus bullying yang juga dikabarkan sangat meningkat. Banyak faktor yang menyebabkan tindakan kekerasan ini terjadi diseluruh Indonesia. Untuk itu melalui penulisan karya ilmiah ini mencoba membatasi permasalahan yang akan dibahas terkait kekerasan terhadap anak di dunia pendidikan di Indonesia dengan perumusan masalah yaitu Pertama, apa saja faktor yang menyebabkan tingginya tindakan kekerasan terhadap anak di sekolah yang terjadi di Indonesia saat ini, Kedua bagaimana tindakan yang dilakukan oleh KPAI dan Pemerintah dalam mengatasi permasalahan kekerasan terhadap di sekolah seperti yang terjadi di Indonesia saat ini ? Untuk itu penulis mencoba untuk memaparkan permasalahan sekaligus analisis terhadap permasalahan yang terjadi tersebut.

\section{METODE PENELITIAN}

Penelitian ini adalah penelitian hukum normatif yang menggunakan metode pengumpulan bahan hukum adalah studi kepustakaan atau studi dokumen (documentary study). ${ }^{10}$ Bahan hukum yang digunakan adalah bahan hukum primer antara lain sekumpulan peraturan perundang-undangan mulai dari UUD Negara Republik Indonesia 1945, Undang-Undang, Putusan Mahkamah Konstitusi, Peraturan Pemerintah dan peraturan perundang-undangan lainnya. Sedangkan bahan hukum sekunder antara lain buku-buku pegangan, majalah hukum, jurnal hukum, skripsi, tesis, disertasi, surat kabar, dan hasil karya ilmiah. ${ }^{11}$

\section{HASIL DAN PEMBAHASAN \\ Teori-Teori tentang Hak Asasi Manusia}

Hak konstitusional merupakan hak-hak individu (individual right) yang dimiliki oleh setiap orang dan tentunya harus mendapatkan penjminan terhadap hak tersebut oleh negara. Pemikiran tentang hak konstitusional ini adalah bersumber dari doktrin yang berasal dari negara barat, dimana hak-hak individu ini dikonsepsikan sebagai hakhak alamiah (natural rights) yang juga tecampur dalam hukum alam. Menurut Thommas Hobbes, setiap individu manusia memiliki hak-hak alamiah (jus naturale) yaitu kebebasan (liberty) untuk menggunakan kekuatannya sendi, sesuai dengan kemauannya sendiri, guna mempertahankan sifat hakikinya dalam kehidupannya. John locke menyatakan hak-hak alamiah sebagai hak atas hidup, kebebasan, dan milik. Menurut Sir William Blackstone hak-hak alamiah adalah perbuatan atau tindakan manusia tunduk pada hukum alam dan bahwa tidak ada satupun hukum buatan manusia dapat dianggap sah (valid) apabila bertentangan dengan hukum alam. ${ }^{12}$

Berbagai upaya untuk mewujudkan HAM dalam kehidupan nyata sejak dahulu hingga saat sekarang ini tercermin dari perjuangan manusia dalam mempertahankan harkat dan martabatnya dari tindakan sewenang-wenang penguasa yang tiran. Timbulnya kesadaran manusia akan hak-haknya sebagai manusia merupakan salah satu faktor penting yang melatarbelakangi dan melahirkan gagasan yang kemudian dikenal sebagai HAM. Hak asasi manusia adalah hak-hak yang dimiliki manusia semata-mata karena ia manusia. Umat manusia memilikinya bukan karena

\footnotetext{
${ }^{8}$ Rahmatul Fauza, "Video Guru Pukul Siswa, Begini Kata Dinas Pendidikan Pangkal Pinang”, Kompas, (6 November 2017)

${ }^{9}$ Andri Donal Putra, "KPAI: Pelaku Kekerasan dan "Bullying” di Sekolah Tahun 2015 Meningkat", Kompas, (30 Desember 2015).

${ }^{10}$ Bambang Waluyo, Penelitian Hukum Dalam Praktek, (Jakarta: Sinar Grafika, 2002), hal. 18-19.

${ }^{11}$ Soerjono Soekanto dan Sri Mamudji, Penelitian Hukum Normatif Suatu Tinjauan Singkat, (Jakarta: Rajawali Press, 2003), hal. 29.

12 Dewa Gede Palguna, Pengaduan Konstitusional (Constitusional Complain), (Jakarta: Sinar Grafika), 2013, hal. 112- 
diberikan kepadanya oleh masyarakat atau berdasarkan hukum positif, melainkan semata-mata berdasarkan martabatnya sebagai manusia. ${ }^{13}$ Dengan demikian, faktor-faktor seperti ras, jenis kelamin, agama maupun bahasa tidak dapat menegasikan eksistensi HAM pada diri manusia. Meskipun beberapa pakar menyatakan dapat merunut konsep HAM yang sederhana sampai kepada filsafat Stoika di zaman kuno lewat yurisprudensi hukum kodrati (natural law) Grotius dan ius naturale dari undang-undang Romawi, tampak jelas bahwa asal usul konsep HAM yang modern dapat dijumpai dalam revolusi Inggris, Amerika Serikat dan Prancis pada abad ke-17 dan ke-18. ${ }^{14}$

Berbagai macam teori HAM menjadi landasan dari adanya hak konstitusional seperti teori hak kodrati yang dikenalkan oleh John Locke. Menurut teori hak-hak kodrati, HAM adalah hak-hak yang dimiliki oleh semua orang setiap saat dan di semua tempat oleh karena manusia dilahirkan sebagai manusia. Hak-hak tersebut termasuk hak untuk hidup, kebebasan dan harta kekayaan. Pengakuan tidak diperlukan bagi HAM, baik dari pemerintah atau dari suatu sistem hukum, karena HAM bersifat universal. Berdasarkan alasan ini, sumber HAM sesungguhnya sematamata berasal dari manusia. Warisan dari teori hak-hak kodrati juga dapat ditemukan dalam berbagai instrumen HAM di benua Amerika dan Eropa. ${ }^{15}$ Dalam perkembangannya teori hak-hak kodrati telah berjasa dalam menyiapkan landasan bagi suatu sistem hukum yang dianggap superior ketimbang hukum nasional suatu negara, yaitu norma HAM internasional.

Tidak semua orang setuju dengan pandangan teori hak-hak kodrati. Teori positivis termasuk salah satunya. Penganut teori ini berpendapat, bahwa mereka secara luas dikenal dan percaya bahwa hak harus berasal dari suatu tempat. Kemudian, hak seharusnya diciptakan dan diberikan oleh konstitusi, hukum atau kontrak. Hal tersebut dikatakan oleh Jeremy Bentham sebagai berikut: "Bagi saya, hak merupakan anak hukum; dari hukum riil lahir hak riil, tetapi dari hukum imajiner, dari hukum 'kodrati', lahir hak imajiner. Hak kodrati adalah omong kosong belaka: hak yang kodrati dan tidak bisa dicabut adalah omong kosong retorik, omong kosong yang dijunjung tinggi." 16 Teori positivisme secara tegas menolak pandangan teori hak-hak kodrati. Keberatan utama teori ini adalah karena hak-hak kodrati sumbernya dianggap tidak jelas. Menurut positivisme suatu hak mestilah berasal dari sumber yang jelas, seperti dari peraturan perundang-undangan atau konstitusi yang dibuat oleh negara. Dengan perkataan lain, jika pendukung hak-hak kodrati menurunkan gagasan mereka tentang hak itu dari Tuhan, nalar atau pengandaian moral yang a priori, kaum positivis berpendapat bahwa eksistensi hak hanya dapat diturunkan dari hukum negara. ${ }^{17}$

Keberatan lainnya terhadap teori hak-hak kodrati berasal dari teori relativisme budaya (cultural relativist theory) yang memandang teori hak-hak kodrati dan penekanannya pada universalitas sebagai suatu pemaksaan atas suatu budaya terhadap budaya yang lain yang diberi nama imperalisme budaya (cultural imperalism). ${ }^{18}$ Menurut para penganut teori relativisme budaya, tidak ada suatu hak yang bersifat universal. Mereka merasa bahwa teori hak-hak kodrati mengabaikan dasar sosial dari identitas yang dimiliki oleh individu sebagai manusia. Manusia selalu merupakan produk dari beberapa lingkungan sosial dan budaya dan tradisi-tradisi budaya dan peradaban yang berbeda yang memuat cara-cara yang berbeda menjadi manusia. Oleh karena itu, hak-hak yang dimiliki oleh seluruh manusia setiap saat dan di semua tempat merupakan hak-hak yang menjadikan manusia terlepas secara sosial (desocialized) dan budaya (deculturized). ${ }^{19}$

Perserikatan Bangsa Bangsa yang lahir setelah perang dunia ke-2 membentuk sebuah gagasan baru tentang hak-hak alamiah mulai disoroti dan diperhatikan. Tujuan dibentuknya PBB pada saat itulah yakni menjadikan pemajuan dan dorongan ke arah penghormatan terhadap hak-hak asasi dan kebebasan mendasar tanpa diskriminasi. Sejak penandatanganan Piagam PBB dan Pembentukan Komisi PBB tentang Hak Asasi Manusia pada tahun 1946, istilah hak-hak alamiah menjadi terkenal sebagai hak asasi manusia yang terkenal yakni Deklarasi Universal HAM (Universal Declaration Of Human Rights). Hak Asasi Manusia diatur secara nyata dalam lingkup internasional dan mendapat respon yang sangat antusias dari berbagai negara dan hal itu ditandai dengan makin banyak negara memasukkan jaminan dan perlindungan HAM itu secara tertulis kedalam konstitusinya. Berawal dari doktrin hak-hak alamiah yang kemudian dikenal menjadi hak-hak asasi manusia berevolusi menjadi hak-hak konstitusional setelah itu dijamin dalam Konstitusi. Demi mencapai cita-cita bernegara salah satu substansi yang dimuat dalam konstitusi negara adalah pengaturan terkait Hak Asasi Manusia (human right) Negara yang menganut sistem rule of law, salah satu unsur yang mutlak harus ada adalah pemenuhan akan hak-hak dasar manusia (basic rights). Hak dasar yang dimuat itu sebagai bentuk pengakuan negara serta sebagai bentuk jaminan perlidungan negara atas hak dasar warga

${ }^{13}$ Rhona K. M. Smith, et. al., Hukum Hak Asasi Manusia, (Yogyakarta: PUSHAM-UII, 2008), hal. 11.

${ }^{14}$ Scott Davidson, Hak Asasi Manusia, Sejarah, Teori dan Praktek dalam Pergaulan Internasional, (Jakarta: Grafiti, 1994), hal. 2.

15 Todung Mulya Lubis, In search of Human Rights Legal-Political Dilemmas of Indonesia's New Order, (Jakarta: Gramedia, 1993), hal. 15-16.

${ }^{16} \mathrm{Ibid}$, hal. 18.

${ }^{17}$ Scott Davidson, Op.Cit. hal. 40.

${ }^{18}$ Todung Mulya Lubis, Op.Cit. hal. 19.

${ }^{19}$ Ibid 
negara, sehingga hak tersebut terlegitimasi secara hukum. Konsekuensi akan hal ini adalah setiap bentuk kebijakan serta peraturan perundang undangan yang diberlakukan tidak boleh melanggar atau meniadakan hak-hak dasar tersebut. ${ }^{20}$

Menurut Jimly Asshiddiqie hak konstitusional (constitutional right) adalah hak-hak yang dijamin di dalam dan oleh UUD Negara Kesatuan Republik Indonesia 1945 baik dinyatakan secara tegas maupun tersirat, karena dicantumkan ke dalam konstitusi maka ia menjadi bagian dari konstitusi. Adanya Pengakuan dan penghormatan terhadap hak-hak konstitusioanl sebagai bagian dari konstitusi dan sebagai pembatasan terhadap kekuasaan negara. Terdaftarnya HAM kedalam konstitusi tertulis berarti memberi kedudukan bahwa hak-hak itu sebagai hak-hak konstitusional. Kontitusi merupakan hukum dasar atau hukum fundamental (fundamental law) maka hak-hak konstitusional juga mendapatkan kedudukan sebagai hak fundamental. ${ }^{21}$ Merujuk dari berbagai pandangan teori-teori di atas, dapat ditarik sebuah benang merah bahwa hak konstitusional merupakan hak yang sangat fundamental, dimana hak ini bukan bersumber dari hak-hak alamiah dan doktrin-doktirn tentang hak alamiah, tetapi lahir dari konstitusi tertulis yang dijamin negara dan merupakan hukum fundamental suatu negara. Hak konstitusional warga negara harus dijamin dalam konstitusi sebagai bentuk pengakuan Hak Asasi Manusia serta perlindungan hak asasi manusia dalam konsep negara hukum tersebut.

\section{Pengaturan Tentang Hak Anak}

Sesuai dengan apa yang diamanatkan oleh konstitusi Indonesia, bahwa setiap warga negara memiliki kedudukan yang sama dihadapan hukum serta peraturan perundang-undangan yang ada di negara tersebut. Kedudukan disini diartikan sebagai hak dan kewajiban yang diatur dalam konstitusi negara. Mengenai permasalahan hak, didalam Pasal 28A UUD 1945 hasil amandemen kedua menyatakan:"Setiap orang berhak untuk hidup serta mempertahankan hidup dan kehidupannya". ${ }^{22}$ Ini dijelaskan bahwa setiap orang di Indonesia atas dasar hak asasi yang dimilikinya berhak untuk hidup dan mempertahankan hidupnya serta dijamin oleh negara atas hal itu. Berbicara hak asasi manusia seperti yang kita ketahui bahwa ini merupakan anugrah dari Tuhan Yang Maha Esa sejak manusia itu dilahirkan. Setiap orang juga memiliki hak untuk berkeluarga dan melanjutkan keturunannya melalui perkawinan yang sah sebagaimana diatur dalam Pasal 28B ayat (1). ${ }^{23}$

Prinsip-prinsip hak asasi manusia yang diatur dalam UUD 1945 berlaku bagi setiap induvidu warga negara Indonesia, termasuk didalamnya anak. Anak memiliki hak yang juga diatur dalam konstitusi kita yaitu pada Pasal 28B ayat (2) yang menyatakan,"Setiap anak berhak atas kelangsungan hidup, tumbuh, dan berkembang, serta berhak atas perlindungan dari kekerasan dan diskriminasi." 24 Sebagaimana yang kita ketahui anak merupakan generasi penerus bangsa yang menjadi sumber daya manusia utama dalam pengembangan bangsa dan negara serta pembangunan nasional. Oleh karena itu negara sangat memiliki peran penting untuk menciptakan anak-anak yang memiliki kemampuan hebat dalam berbagai bidang dan untuk menjadi sumber daya manusia yang berkualitas dan mampu memimpin bangsa dalam memelihara persatuan dan kesatuan NKRI yang berdasarkan pada Pancasila dan Undang Undang Dasar 1945 yang menjadi dasar negara. Untuk mewujudkan itu maka perlu adanya pembinaan dan pengembangan terhadap anak yang merujuk pada hak-hak anak yang harus dilindungi dan dihormati oleh negara.

Landasan hukum yang digunakan dalam melaksanakan pemenuhan hak-hak anak bertumpu pada UndangUndang Dasar Negara republik Indonesia Tahun 1945 seperti yang telah dipaparkan diatas serta prinsip-prinsip dasar Konvensi Hak Anak yang disahkan tahun 1990 kemudian diserap ke dalam Undang-Undang Nomor 23 tahun 2002 dan Undang-Undang Nmor 35 Tahun 2014 tentang Perubahan Atas Undang-Undang Nomor 23 Tahun 2002 Tentang Perlindungan Anak. Berdasarkan sesuatu yang melekat pada diri anak tersebut yaitu hak yang harus dilindungi dan dijaga agar berkembang secara wajar. Menurut Undang Undang Nomor 35 Tahun 2014 tentang Perlindungan Anak yang dikatakan anak adalah seseorang yang belum berusia 18 (delapan belas) tahun, termasuk anak yang masih dalam kandungan.

Menurut Undang-Undang Nomor 4 Tahun 1979 tentang Kesejahteraan Anak Dalam Bab II mengatur tentang hak-hak anak atas kesejahteraan, yaitu:

1. Hak atas kesejahteraan, perawatan, asuhan dan bimbingan.

2. Hak atas pelayanan.

3. Hak atas pemeliharaan dan perlindungan.

4. Hak atas perlindungan lingkungan hidup.

5. Hak mendapatkan pertolongan pertama.

${ }^{20}$ Pipin Lestari, Hak Konstitusional Pemenuhan Pendidikan Di Daerah Pendudukan, Skripsi Universitas Lampung, 2016, hal. 38.

${ }^{21}$ Dewa Gede Palguna, Op. Cit.

${ }^{22}$ Indonesia, Undang Undang Dasar Negara Republik Indonesia Tahun 1945 Amandemen ke II, Pasal 28A.

${ }^{23}$ Indonesia, Undang Undang Dasar Negara Republik Indonesia Tahun 1945 Amandemen ke II, Pasal 28B ayat (1).

${ }^{24}$ Indonesia, Undang Undang Dasar Negara Republik Indonesia Tahun 1945 Amandemen ke II, Pasal 28B ayat (2). 
6. Hak untuk memperoleh asuhan.

7. Hak untuk memperoleh bantuan.

8. Hak diberi pelayanan dan asuhan.

9. Hak untuk memeperoleh pelayanan khusus.

10.Hak untuk mendapatkan bantuan dan pelayanan

Selain itu hak anak juga diatur dalam Undang Undang Nomor 39 Tahun 1999 tentang Hak Asasi Manusia, dimana hak anak diatur secara khusus sebagai berikut:

Adapun Hak Asasi Anak Menurut Undang-Undang Nomor 39 Tahun 1999, meliputi:

1. Anak mendapat perlindungan orang tua, masyarakat dan negara (Pasal 62 ayat (1)).

2. Hak melindungi sejak dari dalam kandungan (Pasal 52 ayat (1)).

3. Hak hidup dan meningkatkan taraf kehidupan (Pasal 53 ayat (1)).

4. Hak mendapat nama dan status kewarganegaraan (Pasal 53 ayat (2)).

5. Hak mendapat perawatan, pendidikan, pelatihan dan bantuan khusus anak cacat fisik atau mental (Pasal 54).

6. Hak untuk beribadah menurut agamanya, berpikir dan berekspresi (Pasal 55).

7. Hak mengetahui, dibesarkan dan diketahui orang tuanya (Pasal 56 ayat (1)).

8. Hak diasuh dan diangkat anak oleh orang lain (Pasal 56 ayat (2)).

9. Hak dibesarkan, dipelihara, dirawat, dididik, diarahkan dan dibimbing orang tua/wali (Pasal 57 ayat (1)).

10. Hak mendapatkan orang tua angkat atau wali (Pasal 57 ayat (2)).

11. Hak perlindungan hukum (Pasal 58 ayat (1)).

12. Hak pemberatan hukuman bagi orang tua, wali/pengasuh yang menganiaya anak (fisik, mental, penelantaran, perlakuan buruk dan pelecehan seksual dan pembunuhan (Pasal 58 ayat (2)).

13. Hak tidak dipisahkan dari orang tua (Pasal 59 ayat (1)).

14. Hak bertemu dengan orang tua (Pasal 59 ayat (2)).

15. Hak memperoleh pendidikan dan pengajaran (Pasal 60 ayat (1)).

16. Hak mencari, menerima dan memberikan informasi (Pasal 60 ayat (2)).

17. Hak untuk beristirahat, bergaul dengan anak sebaya, bermain, berekreasi (Pasal 62).

18. Hak memperoleh pelayanan kesehatan dan jaminan sosial (Pasal 62).

19. Hak tidak dilibatkan dalam peperangan, sengketa bersenjata, kerusuhan sosial dan peristiwa kekerasan (Pasal 63).

20. Hak perlindungan hukum dari eksploitasi ekonomi dan pekerjaan yang membahayakan dirinya (Pasal 64).

21. Hak perlindungan dari kegiatan eksploitasi dan pelecehan seksual, penculikan, perdagangan anak dan dari penyalahgunaan narkotika, psikotropika dan zat adiktif lainnya (Pasal 65).

22. Hak tidak dijadikan sasaran penganiayaan, penyiksaan, atau penjatuhan hukuman yang tidak manusiawi (Pasal 66 ayat (1)).

23. Hak tidak dapat dijatuhi hukuman mati atau hukuman seumur hidup (Pasal 66 ayat (2)).

24. Hak tidak dirampas kemerdekaannya secara melawan hukum (Pasal 66 ayat (3)).

25. Hak penangkapan, penahanan atau pidana penjara hanya sebagai upaya terakhir (Pasal 66 ayat (4)).

26. Hak perlakuan yang manusiawi bagi anak yang dirampas kemerdekaannya dan dipisahkan dari orang dewasa (Pasal 66 ayat (5)).

27. Hak bantuan hukum dan bantuan lainnya secara efektif bagi anak yang dirampas kebebasannya (Pasal 66 ayat $(6))$.

28. Hak membela diri dan memperoleh keadilan bagi anak yang dirampas kebebasannya di depan pengadilan yang objektif, tidak memihak dan sidang tertutup untuk umum. ${ }^{25}$

Berdasarkan prinsipnya hak-hak anak dikategorikan dalam empat prinsip utama yang diterapkan dalam Konvensi Hak Anak yang saat ini diratifikasi dalam Undang Undang Nomor 10 Tahun 2012 tentang Konvensi Hak Anak, lalu diserap oleh Undang Undang Nomor 23 Tahun 2002 tentang Perlindungan Anak yang dirinci sebagai berikut $^{26}$ :

1. Prinsip Nondiskriminasi

Ini diartikan bahwa perlindungan anak dilakukan sesuai dengan prinsip-prinsip pokok yang terdapat dalam Konvensi Hak Anak. Dimana prinsip ini tertuang dalam Pasla 2 Konvensi Anak yaitu," Negara-negara peserta akan menghormati dan menjamin hak-hak yang diterapkan dalam konvensi ini bagi setiap anak yang berada dalam wilayah hukum mereka tanpa diskriminasi dalam bentuk apapun, tanpa memandang ras, warna kulit, jenis kelamin, bahasa, agama, pandangan politik atau pandangan-pandangan lain, asal-usul kebangsaan, etnik atau sosial, status kepemilikan, cacat atau tidak, kelahiran atau status lainnya baik dari si anak sendiri atau dari orang tua atau walinya yang sah". (Ayat 1). "Negara-negara peserta akan mengambil semua langkah yang perlu untuk menjamin

\footnotetext{
${ }^{25}$ Prints, Darwan, Hukum Anak Indonesia,(Bandung: PT. Citra Aditya Bakti 2003), hal. 144

${ }^{26}$ Supriyadi W. Eddyono, Pengantar Konvensi Hak Anak, (Jakarta: ELSAM, 2005), hal. 2.
} 
agar anak dilindungi dari semua bentuk diskriminasi atau hukuman yang didasarkan pada status, kegiatan, pendapat yang dikemukakan atau keyakinan dari orang tua anak, walinya yang sah atau anggota keluarga". (Ayat 2).

2. Prinsip Kepentingan yang terbaik bagi anak (The best interest of the child).

Bahwa dalam semua tindakan yang menyangkut anak dilakukan oleh pemerintah, masyarakat, badan legislatif dan yudikatif, maka kepentingan anak harus menjadi pertimbangan utama.

3. Prinsip Hak untuk hidup, kelangsungan hidup, dan perkembangan (the rights to life, survival and development).

Artinya dengan asas hak untuk hidup, kelangsungan hidup, dan perkembangan adalah hak asasi yang paling mendasar bagi anak yang dilindungi oleh Negara, pemerintah, keluarga, dan orang tua. Sedangkan hal itu merupakan hak setiap manusia yang paling asasi.

4. Prinsip Penghargaan terhadap pendapat anak (resepct for the views of the child).

Artinya dengan asas penghargaan terhadap pendapat anak adalah penghormatan atas hak-hak untuk berpartisipasi dan menyatakan pendapatnya dalam pengambilan keputusan tersebut menyangkut hal-hal yang mempengaruhi kehidupannya.

Dengan adanya penegasan prinsip hak anak dalam Konvensi Hak Anak ini, maka selanjutnya di dalam Undang Undang Nomor 23 Tahun 2002 tentang Perlindungan Anak juga diatur tegas tentang apa saja yang menjadi hak-hak anak sehingga menciptakan sbeuah norma baru terkait hak-hak anak untuk hidup, berkembang, perlindungan dan partisipasi yang wajar. ${ }^{27}$ Bentuk kongkret dari norma hukum utama dalam Undang Undang Nomor 23 Tahun 2002 tentang Perlindungan Anak ini yaitu pada Pasal 4 inilah yang dikatakan norma hukum utama karena merupakan tonggak awal untuk inspirasi pada norma hukum berikutnya dalam pasal-pasal selanjutnya. Mengenai Hak-Hak Anak diatur dalam Pasal 4 s/d Pasal 19 yang secara garis besar dikategorikan dalam empat kategori yaitu :

1. Hak kelangsungan hidup yang mencakup hak dan memperoleh pelayanan kesehatan yang memadai (survival rights).

2. Hak tumbuh kembang anak yang mencakup semua jenis pendidikan formal maupun formal dan hak menikmati standart kehidupan yang layak bagi tumbuh kembang fisik, mental, spritual, moral non moral dan sosial (development rights).

3. Hak perlindungan yang mencakup perlindungan diskriminasi, penyalahgunaan dan pelalaian, perlindungan anakanak tanpa keluarga dan perlindungan bagi anak anak pengungsi (protection rights).

4. Hak partisipasi yang meliputi hak-hak anak untuk menyampaikan pendapat/pandangannya dalam semua hal yang menyangkut nasib anak itu (participation rights). ${ }^{28}$

Namun demikian, walaupun seluruh hak anak dijamin oleh negara, anak juga tidak terlepas dari kewajiban yang juga diatur dalam Undang Undang Nomor 23 Tahun 2002 tentang Perlindungan Anak yang mengkategorikan kewajiban yang harus dilakukan oleh anak adalah sebagai berikut :

1. Menghormati orang tua, wali, dan guru.

2. Mencintai keluarga, masyarakat, dan menyayangi teman.

3. Mencintai tanah air, bangsa, dan negara.

4. Menunaikan ibadah sesuai dengan ajaran agamanya.

5. Melaksanakan etika dan akhlak yang mulia. ${ }^{29}$

\section{Analisis Permasalahan}

\section{Penyebab Timbulnya Kekerasan Terhadap Anak di Sekolah}

Salah satu hak anak yang menjadi perhatian negara adalah hak tumbuh kembang anak untuk mendapatkan pendidikan formal yang mana bersumber dari Pasal 31 Undang Undang Dasar Negara Republik Indonesia 1945,"Setiap warga negara berhak mendapatkan pendidikan". Setiap disini mewakili seluruh warga negara termasuk yang paling utama adalah anak. Lalu berdasarkan amanat konstitusi ini selanjutnya diatur secara lanjut dalam Undang Undang Nomor 35 Tahun 2014 tentang Perubahan atas Undang Undang Nomor 23 Tahun 2002 tentang Perlindungan Anak Pasal 9 ayat (1) yang menyatakan,"Setiap Anak berhak memperoleh pendidikan dan pengajaran dalam rangka pengembangan pribadinya dan tingkat kecerdasannya sesuai dengan minat dan bakat." ${ }^{30}$ Selanjutnya dalam Pasal 9 Ayat (1) huruf a menyatakan juga bahwa,"Setiap Anak berhak mendapatkan perlindungan di satuan pendidikan dari kejahatan seksual dan Kekerasan yang dilakukan oleh pendidik, tenaga kependidikan, sesama peserta didik, dan/atau

${ }^{27}$ Muhammad Joni, Hak-Hak Anak dalam UU Perlindungan Anak dan Konvensi PBB tentang Hak Anak: Beberapa Isu Hukum Keluarga, (Jakarta: KPAI, t.t.,), hal. 11.

${ }^{28}$ Ibid, hal. 16.

${ }^{29}$ Ibid

${ }^{30}$ Indonesia, Undang Undang Perlindungan Anak, UU No. 35 Tahun 2014, LN No. 297 Tahun 2014, TLN No. 5606, Pasal 9 ayat (1). 
pihak lain." ${ }^{31}$ Adanya Ayat (1) huruf a ini ada dikarenakan banyaknya perkembangan kasus kekerasan yang terjadi terhadap anak di sekolah yang mana pelakunya adalah tenaga pendidik itu sendiri, siswa, pengurus sekolah atau pihak lain diluar sekolah. Hal ini terlihat jelas pada banyaknya tindakan kekerasan yang muncul di media sosial terkait penganiayaan atau kekerasan fisik yang terjadi saat ini.

Sekolah yang merupakan tempat untuk menempa ilmu dan moral yang baik saat ini sudah menjadi tempat bagi para pelaku kekerasan terhadap anak. Kekerasan yang terjadi di sekolah terutama yang dilakukan oleh guru mereka sendiri, hal ini terjadi karena guru tidak paham akan makna kekerasan dan akibat negatifnya. Guru mengira bahwa murid akan jera karena hukuman fisik. Sebaliknya, murid menjadi benci dan tidak patuh lagi pada guru. Kekerasan dalam pendidikan terjadi dikarenakan kurangnya kasih sayang dari guru. Guru seharusnya memperlakukan murid sebagai subyek bukan sebagai objek. Kekerasan bisa terjadi karena guru sudah tidak memiliki atau sangat kurang memiliki rasa kasih sayang terhadap murid, atau dahulu guru itu sendiri diperlakukan dengan keras. Sekolah yang seharusnya menjadi tempat untuk berprestasi, tetapi menjadi ajang premanisme. Sekolah yang seharusnya menjadi tempat belajar tentang norma-norma kemasyarakatan yang baik, tetapi dijadikan rimba tanpa hukum. Guru yang kuat, berkuasa, memiliki legalitas untuk menindas yang lain. Kekerasan sering terjadi bukan dalam bentuk kekerasan fisik, tetapi juga kekerasan psikis. Hal-hal yang sepele dapat menjadi alasan untuk melakukan kekerasan. Bahkan terkadang kekerasan dilakukan tanpa alasan. Menjadi suatu pertanyaan besar jika kekerasan terjadi dari pihak guru kepada siswa. Hal ini sangat memalukan dunia pendidikan. Guru yang seharusnya menjadi contoh yang baik bagi para murid, malah memberikan contoh yang tidak baik kepada murid-murid. ${ }^{32}$

Tahun 2016 terjadi kasus penganiayaan pada murid Sekolah Menengah Pertama yang terjadi di Pangkal Pinang, dalam video singkat berdurasi 37 detik tersebut terlihat bahwa seorang guru tengah memukul anak didiknya dua orang secara bergantian. ${ }^{33}$ Sangat disayangkan sekali kondisi pendidikan di Indonesia saat ini, dimana tenaga pendidik yang menjadi panutan bagi siswa melakukan tindakan kekerasan yang nantinya dapat menyebabkan terganggunya psikologi anak dalam menuntut ilmu. Selain itu masih ada lagi kasus kekerasan yang terjadi di dalam dunia pendidikan seperti yang dikatakan oleh Sukiman Direktur Pembinaan Pendidikan Keluarga Kementerian pendidikan dan Kebudayaan RI bahwa angka kekerasan di lingkungan sekolah yang dialami siswa masih cukup tinggi. Kondisi itu dipengaruhi oleh anggapan yang menyebutkan bahwa kekerasan itu bagian dari pendidikan. Hal itu disampaikannya dalam seminar pendidikan di Fakultas Ilmu Pendidikan Universitas Negeri Malang, Jawa Timur. Dia mengatakan bahwa "Ada yang masih menganggap bahwa itu bagian dari pendidikan. Bahwa pendisiplinan itu melalui kekerasan," itu lah yang menyebabkan guru memukul siswa dikelas. ${ }^{34}$

Berdasarkan data International Center for Research on Women (ICRW) Pada 2015, sebanyak 84 persen siswa di Indonesia mengaku pernah mengalami kekerasan di sekolah. Sebanyak 45 persen siswa laki-laki menyebutkan bahwa guru atau petugas sekolah merupakan pelaku kekerasan. Adapun 22 persen siswi menyebutkan bahwa guru dan petugas sekolah merupakan pelaku kekerasan. Selain itu, 75 persen siswa mengakui pernah melakukan kekerasan di sekolah. Berdasarkan data United Nations International Children's Emergency Fund (UNICEF), 50 persen anak mengaku pernah mengalami perundungan atau bullying di sekolah. Adapun 40 persen pelajar berusia 13-15 tahun mengaku pernah mengalami kekerasan oleh teman sebaya. ${ }^{35}$ Kondisi ini bertentangan dengan hak konstitusi yang merupakan hak-hak individu (individual Rights) yang dimiliki oleh setiap orang dan tentunya harus mendapatkan penjaminan terhadap hak itu oleh negara. Jimly Asshiddiqie menyatakan hak konstitusional (constitutional right) adalah hak-hak yang dijamin di dalam dan oleh UUD Negara Kesatuan Republik Indonesia 1945 baik dinyatakan secara tegas maupun tersirat, karena dicantumkan ke dalam konstitusi maka ia menjadi bagian dari konstitusi. Pasal 28B ayat (2) UUD Negara Republik Indonesia 1945 telah menyatakan dengan tegas bahwa: Setiap anak berhak atas kelangsungan hidup, tumbuh, dan berkembang, serta berhak atas perlindungan dari kekerasan dan diskriminasi.

Tindak kekerasan yang terjadi berdasarkan data di atas merupakan gambaran tindakan yang dilakukan oleh tenaga pendidik, atau siswa sendiri atau juga pihak lain di luar sekolah, dikatakan bahwa 84 persen siswa pernah mengalami kekerasan di sekolah yang dilakukan oleh tenaga pendidik. Angka ini sangat tinggi sekali. Kekerasan yang dialami oleh anak dikategorikan dalam 3 kelompok yaitu kekerasan fisik, kekerasan mental dan kekerasan seksual. Sebagai bentuk gejala sosial budaya, tindakan terhadap anak ini tidak muncul begitu saja dalam keadaan netral. Tentunya ada kondisi budaya tertentu dalam masyarakat seperti berbagai pandangan, nilai dan norma sosial yang memudahkan terjadinya tindakan kekerasan ini. dari wawancara yang dilakukan dengan Direktur Pembinaan Pendidikan Kemendikbud diatas, beberapa data yang dapat ditampilkan bahwa kekerasan yang dilakukan di sekolah

${ }^{31}$ Indonesia, Undang Undang Perlindungan Anak, UU No. 35 Tahun 2014, LN No. 297 Tahun 2014, TLN No. 5606, Pasal 9 ayat (1a).

32 Arthur Rionaldi, Tinjauan Yuridis Terhadap Kekerasan Yang Dilakukan Oknum Guru Terhadap Murid Di Sekolah, Jurnal Ilmu Hukum, 2014, hal. 4.

${ }^{33}$ Rahmatul Fauza, Video Guru Pukul Siswa, Op.Cit.

${ }^{34}$ Andi Hartik, 84 Persen Siswa Indonesia Alami Kekerasan di Sekolah, Kompas, (29 November 2016).

${ }^{35}$ Ibid 
ada 3 besar, yaitu Pertama, kekerasan yang dilakukan oleh guru atau tenaga pendidik disekolah, Kedua, kekerasan berupa perundungan (Bullying), dan yang Ketiga, kekerasan yang dilakukan oleh siswa terhadap siswa lain yang sering kita kenal dengan tawuran.

Merujuk pada tiga kategori kekerasan ini, berikut ini data mengenai anak korban kasus kekerasan disekolah (Bullying) dan anak pelaku kekerasan (Bullying) berdasarkan data dari Komisi Perlindungan Anak Indonesia: ${ }^{36}$

Tabel 1. Data Korban Bullying

\begin{tabular}{llllllll}
\hline No & Kasus Perlindungan Anak & $\mathbf{2 0 1 1}$ & $\mathbf{2 0 1 2}$ & $\mathbf{2 0 1 3}$ & $\mathbf{2 0 1 4}$ & $\mathbf{2 0 1 5}$ & $\mathbf{2 0 1 6}$ \\
\hline 603 & Anak Korban Kekerasan di Sekolah (Bullying) & 56 & 130 & 96 & 159 & 154 & 81 \\
\hline
\end{tabular}

Tabel 2. Data Pelaku Bullying

\begin{tabular}{ccllllll}
\hline No & Kasus Perlindungan Anak & $\mathbf{2 0 1 1}$ & $\mathbf{2 0 1 2}$ & $\mathbf{2 0 1 3}$ & $\mathbf{2 0 1 4}$ & $\mathbf{2 0 1 5}$ & $\mathbf{2 0 1 6}$ \\
\hline 604 & Anak Pelaku Kekerasan di Sekolah (Bullying) & 48 & 66 & 63 & 67 & 93 & 93 \\
\hline
\end{tabular}

Berikut tampilan data mengenai anak korban kasus tawuran pelajar dan anak pelaku pelaku tawuran pelajar berdasarkan data dari Komisi Perlindungan Anak Indonesia: ${ }^{37}$

Tabel 3. Data Korban Tawuran

\begin{tabular}{llllllll}
\hline No & Kasus Perlindungan Anak & $\mathbf{2 0 1 1}$ & $\mathbf{2 0 1 2}$ & $\mathbf{2 0 1 3}$ & $\mathbf{2 0 1 4}$ & $\mathbf{2 0 1 5}$ & $\mathbf{2 0 1 6}$ \\
\hline 601 & Anak Korban Tawuran Pelajar & 20 & 49 & 52 & 113 & 96 & 26 \\
\hline
\end{tabular}

Tabel 4. Data Pelaku Tawuran

\begin{tabular}{llllllll}
\hline No & Kasus Perlindungan Anak & $\mathbf{2 0 1 1}$ & $\mathbf{2 0 1 2}$ & $\mathbf{2 0 1 3}$ & $\mathbf{2 0 1 4}$ & $\mathbf{2 0 1 5}$ & $\mathbf{2 0 1 6}$ \\
\hline 602 & Anak Pelaku Tawuran Pelajar & 64 & 82 & 71 & 46 & 126 & 41 \\
\hline
\end{tabular}

Berdasarkan data tersebut ditemukan banyak sekali peningkatan korban kasus kekerasan disekolah (bullying) meningkat di tahun 2014, dan kekerasan tawuran antar pelajar juga sangat meningkat pada tahun 2014.

Kasus ini tidak hanya terjadi di Indonesia saja, terutama kasus bullying juga menjadi sorotan di Amerika, data kasus bullying di Amerika dilaporkan oleh Josephson Institute of Ethics yang telah melakukan survei pada 43000 remaja, hasilnya 47\% remaja berusia 15 hingga 18 tahun telah mengalami bullying dan 50\% dari remaja tersebut telah mengganggu, menggoda, dan mengejek siswa lain. National Association of Elementary School Principals melaporkan bahwa setiap tujuh menit anak dibully di lingkungan sekolah, dan setiap bulan ada tiga juta murid absen dari sekolah karena merasa tidak nyaman. Diperkirakan ada 18 juta anak telah dibully di tahun 2013. ${ }^{38}$ Menurut Rigby, bullying berhubungan dengan keinginan menyakiti, dan tindakan menyakiti orang lain . Bullying adalah perilaku agresif pada anak-anak yang melibatkan ketidakseimbangan kekuatan. Perilaku bullying dilakukan secara berulang-ulang dari waktu ke waktu. Bullying termasuk tindakan seperti membuat ancaman, menyebarkan gosip, menyerang seseorang secara fisik dan verbal yang dilakukan mengatasnamakan individu dan kelompok berdasarkan hasil penelitian dari Department of Health \& Human Services USA, di tahun 2015. Bullying adalah bentuk perilaku agresif di mana seseorang dengan sengaja dan secara berulang membuat orang lain menjadi cedera atau membuat orang lain tidak nyaman. Bullying dapat berupa kontak fisik dan kata-kata.Individu diganggu biasanya memiliki kesulitan membela dirinya sendiri dan tidak melakukan apapun menurut data dari American Psychological Association tahun 2016. ${ }^{39}$

Berdasarkan data di atas, tindakan kekerasan yang sering terjadi di sekolah Amerika Serikat adalah bullying. Kisaran tahun 2013 sampai 2015 angka kekerasan terhadap bullying meningkat di USA, dikatakan pada data diatas bahwa tindakan bullying ini merupakan aksi dari tekanan yang dilakukan oleh teman sebaya yang menyebabkan anakanak korban bullying mengalami depresi sehingga memutuskan untuk bolos sekolah daripada mendapatkan tekanan dari teman mereka. Kita bandingkan angka kekerasan yang terjadi di Amerika dan Indonesia diantara Tahun 2013-

36 Komisi Perlindungan Anak Indonesia, "Rincian Data Kasus Berdasarkan Klaster tahun 2011-2016", http://bankdata.kpai.go.id/tabulasi-data/data-kasus-per-tahun/rincian-data-kasus-berdasarkan-klaster-perlindungan-anak-2011$\underline{2016}$, diakese pada 15 November 2017.

${ }^{37}$ Ibid

38 Andi Halimah, et.al., "Persepsi Pada Bystander Terhadap Intensitas Bullying pada Siswa SMP”, Jurnal Psikologi Volume 42, No. 2 (Agustus 2015), hal. 129-140.

${ }^{39}$ Rina Fataruba, "Peran Tekanan Teman Sebaya Terhadap Perilaku Bullying pada Remaja di Sekolah", Seminar ASEAN Kedua Psychology dan Humanity, Psychology Forum UMM, (19-20 Februari 2016), hal. 356. 
2015 mendapati angka tertinggi terkait kasus ini, Indonesia pada tahun 2014 perilaku bullying ini sangat meningkat, Hasil riset yang didanai UNICEF dan dilaksanakan Kementerian Komunikasi dan Informatika menemukan fakta sebanyak 30 juta anak dan remaja Indonesia merupakan pengguna internet sehingga media digital kini menjadi pilihan utama saluran komunikasi mereka berdasarkan riset di Tahun $2014 .{ }^{40} \mathrm{Hal}$ ini menunjukkan bahwa dengan penggunaan gadget pada anak untuk syarat perkembangan bagi mereka memberikan dampak buruk dari apa yang mereka lihat melalui internet. Internet benar-benar membuka cakrawala anak dan jika tidak dikontrol bisa terlalu bebas dan menyebabkan mereka dengan mudah mengakses apapun itu dari internet, salah satunya permainan game online yang identik dengan peperangan dan kekerasan yang menyebabkan anak ikut-ikutan mempraktekkan kepada teman sebayanya, lalu melihat kebebasan media sosial untuk meng-upload kejadian yang tidak seharusnya ditonton anak seperti bullying, lalu dijadikan contoh anak-anak untuk diprakterkan kepada temannya.

Namun demikian, tindakan kekerasan yang berkembang saat ini di sekolah tidak hanya dilakukan oleh anak murid kepada temannya saja, tetapi guru pun juga melakukan perbuatan yang tidak sepantasnya dilakukan kepada murid untuk sebuah alasan didikan. Tindakan kekerasan yang dilakukan oleh guru di sekolah terhadap siswanya dapat saja disebabkan oleh beberapa hal berikut $:^{41}$

1. Guru dinilai kurang memiliki pengetahuan mengenai efek dari kekerasan itu sendiri. Kekerasan baik secara fisik dan psikis yang dianggap ampuh mendisiplinkan murid ternyata tidak efektif untuk mengubah perilaku siswa serta memotivasinya, malah akan berisiko menimbulkan trauma psikologis dan melukai harga dirinya.

2. Cenderung memiliki persepsi yang parsial dalam menilai siswa. Kebanyakan guru hanya melihat tindakan murid dari permukaannya saja tanpa mencari tahu apa yang melandasi tindakan atau sikap murid tersebut. Guru perlu mengetahui bahwa setiap muridnya memiliki latarbelakang yang tidak dapat dilepaskan dalam setiap tindakan yang ia lakukan.

3. Guru memiliki masalah psikologis yang membuatnya tidak mampu mengendalikan emosi sehingga guru tersebut cenderung lebih sensitif dan reaktif.

4. Adanya tekanan dalam pekerjaan. Setiap guru tentu menargetkan anak didiknya berhasil meraih prestasi, namun dalam mencapai tujuan tersebut tentu ada kendala yang besar.

5. Pola pengajaran yang masih menganut otoritarian. Pola ini mengutamakan kepatuhan pada figur otoritas yang dalam hal ini adalah guru. Proses belajar mengajar bersifat satu arah, dari guru ke murid. Sehingga murid cenderung tidak memiliki kesempatan untuk mengekspresikan pendapat dan guru merasa memiliki kekuasaan lebih terhadap murid-muridnya.

6. Muatan kurikulum yang menekankan pada kemampuan kognitif dan cenderung mengabaikan kemampuan afektif. Tidak menutup kemungkinan suasana belajar jadi kering dan stressfull, dan pihak guru pun kesulitan dalam menciptakan suasana belajar mengajar yang menarik, padahal mereka dituntut mencetak murid murid berprestasi.

Faktor lain yang menyebabkan guru melakukan kekerasan terhadap siswa nya, yaitu sikap murid yang tidak dapat terlepas dari dimensi psikologis dan kepribadian murid itu sendiri. Perasaan bahwa dirinya lemah, tidak pandai, tidak berguna, tidak berharga, tidak dicintai, kurang diperhatikan, rasa takut diabaikan, bisa saja membuat seorang murid menjadi berbuat aneh. Sehingga hal itu memicu amarah guru dikelas.

Sedangkan tindakan kekerasan yang dilakukan oleh siswa itu sendiri terhadap temannya dikarena beberapa faktor berikut :

1. Faktor sosial anak, hal ini lebih kepada interaksi anak dengan teman sebaya nya yang biasa melakukan kekerasan, lantaran terbiasa ini anak menganggap bahwa kekerasan yang dilakukannya adalah wajar;

2. Faktor lingkungan, hal ini juga mempengaruhi anak untuk melakukan tindakan kekerasan terhadap teman sebayanya, seperti kebiasaan menggunakan gadget untuk melakukan permainan perang-perangan, kemudian oleh anak dipraktekkan kepada teman sekelasnya, imbas dari film ataupun video game yang bersifat kekerasan. Lewat berbagai media tersebut, anak menjadi terbiasa dengan kekerasan, sehingga walaupun tidak melakukan kekerasan, dalam banyak kasus anak diketahuinya membiarkan terjadinya kekerasan;

3. Faktor disfungsi keluarga, anak yang berasal dari latar belakang keluarga yang buruk memiliki potensi besar akan melakukan kekerasan. Keluarga yang tidak harmonis mempengaruhi psikologis anak secara bertahap.

4. Faktor Bullying yang dialami anak dilingkungan rumah/sekolah. Pengalaman buruk ini bisa berbentuk verbal atau psikis akan dilakukan oleh anak terhadap temannya atau bahkan orang lain. ${ }^{42}$

\footnotetext{
${ }^{40}$ Didi Purwadi, "Riset : 30 Juta Anak Indonesia Pengguna Gadget", Republika, (18 Februari 2014)

${ }^{41}$ Ibu dan Mama, "Kekerasan Yang Terjadi di Sekolah",http://www.ibudanmama.com/pola-asuh/kekerasan-yang-terjadidi-sekolah/, kekerasan yang terjadi di sekolah, diakses tanggal 15 November 2017.

${ }^{42}$ Dedi Hendrian, "Banyak Alasan Remaja Melakukan Kekerasan", http://www.kpai.go.id/berita/kpai-banyak-alasanremaja-lakukan-kekerasan/, diakses pada 19 November 2017.
} 


\section{Upaya Penyelesaian Permasalahan Kekerasan terhadap Anak di Sekolah}

Terhadap segala macam tindakan kekerasan yang terjadi saat ini di Indonesia terhadap anak di sekolah, menjadi tugas besar dari negara yang notabene adalah penyelenggara perlindungan hak anak di Indonesia sesuai anak konstitusi. Melihat data yang dipaparkan diatas, kekerasan terhadap anak sangat meningkat pada tahun 2014, jenis kekerasan yang meningkat itu adalah bullying yang dilakukan oleh guru atau siswa terhadap temannya, dan kekerasan tawuran yang dilakukan siswa sebaya. Menyrotoi hal ini KPAI mengambil langkah untuk menghadapi kasus kekerasan yang terjadi di sekolah ini dengan mengimbau agar sekolah ikut terlibat melakukan perlindungan terhadap anak dari aksi kejahatan. saat ini sekolah hanya berfokus pada aspek pengajaran, namun minim partisipasi mendeteksi dugaan kasus kekerasan terhadap anak. Idealnya sekolah perlu turut terlibat dalam pengawasan anak didiknya. ada beberapa peran yang bisa diambil sekolah untuk turut melindungi anak atau siswanya. Pertama, sekolah bisa turut memperhatikan gerak gerik siswa apakah sang anak berpotensi menjadi korban kekerasan atau tidak. Kedua, sekolah perlu membangun mekanisme pencegahan dan penanganan kekerasan. Ketiga, sekolah dapat membangun kelompok sebaya untuk mencegah terjadinya aksi kekerasan antar siswa di sekolah. Keempat, sekolah juga penting untuk berperan aktif memberikan edukasi kepada para orang tua agar bisa menerapkan pola asuh yang ramah terhadap anak. Kelima, jika ada dugaan anak menjadi korban kekerasan, sekolah harus melaporkan kepada kepolisian. ${ }^{43}$

Upaya yang dapat dilakukan untuk mencegah terjadinya tindak kekerasan guru di sekolah adalah solusi yang diberikan untuk mengatasi kekerasan guru pada siswa di sekolah diantaranya adalah sebagai berikut:

1. Menerapkan pendidikan tanpa kekerasan di sekolah;

2. Mendorong/mengembangkan humaniasi pendidikan;

3. Hukuman yang di berikan berkolerasi dengan tindakan anak;

4. Terus menerus membekali guru untuk menambah wawasan pengetahuan, kesempatan, pengalaman baru untuk mengembangkan kreativitas mereka;

5. Bukan murid saja membutuhkan konseling, tapi juga guru. Sebab guru juga mengalami masa sulit yang membutuhkan dukungan, penguatan, atau bimbingan untuk menemukan jalan keluar yang terbaik. ${ }^{44}$

Menumbuhkan kesadaran kepada pendidik selain menjadi pengajar, seseorang guru juga berperan sebagai seorang pendidik dan motivator bagi siswa-siswanya. Sebagai seorang pengajar, guru dituntut bekerja cerdas dan kreatif dalam mentransformasikan ilmu atau materi kepada siswa,dan guru juga dituntut unuk menanamkan nilai moral, kedisiplinan, sopan santun, dan ketertiban dan peraturan disekolah dan seorang guru dalam mendidik seharusnya jika mengucapkan sesuatu dalam menegur atau mengkritik itu harus dengan bahasa yang sopan, tidak boleh manggunakan bahasa yang sarkasme, apalagi jika guru sampai melakukan tindak kekerasan secara fisik. Menumbuhkan kesadaran kepada anak didik juga tentang kekerasan dan bahaya kekerasan dan akibat yang akan ditimbulkan. Dan pemberlakuan sanksi yang seharusnya diberlakukan jika sanksi itu tidak diberlakukan dengan mestinya takutnya kasus kekerasan itu akan semakin marak. Dengan pemberlakuan sanksi yang tegas akan meminimalisir kasus kekerasan. ${ }^{45}$

Setiap orangtua tentu menginginkan anaknya menuntut ilmu di sekolah yang dapat menjamin keselamatan anaknya. Terutama orangtua yang bekerja tentunya tidak memiliki waktu untuk mengawasi anaknya selama di sekolah. Agar anak Anda terhindar dari tindak kekerasan di sekolah, ada baiknya Anda serta pihak sekolah bekerjasama untuk mencegah tindak kekerasanterjadi di sekolah. Adapun langkah yang bisa diambil dalam rangka mencegah kekerasan terjadi pada anak saat di sekolah, sebagai berikut:

1. Memanfaatkan teknologi.

Sekolah dapat memanfaatkan berbagai alat seperti kamera CCTV dan metal detectors untuk mencegah adanya benda-benda berbahaya masuk ke gedung sekolah.

2. Memonitor murid.

Para guru seharusnya mengawasi perilaku muridnya baik di dalam maupun di luar kelas. Jika menemukan siswa yang berisiko menimbulkan tindak kekerasan, terus awasi perilaku anak tersebut, dan juga laporkan ke pihak tertinggi sekolah, seperti kepala sekolah. Selain itu, ada baiknya guru sering-sering berinteraksi dengan muridnya, dan laporkan baik pada pihak sekolah maupun orangtua apabila ada perubahan perilaku yang drastis dari murid tersebut.

3. Menjelaskan aturan sekolah.

Sekolah harus menjelaskan segala aturan dan kebijakan sekolah kepada (calon) siswa dan orangtua murid saat pendaftaran sekolah. Peraturan-peraturan yang harus dipatuhi siswa serta konsekuensi yang akan diberikan kepada siswa yang melanggarnya (termasuk tindak kekerasan).

4. Mengadakan workshop pencegahan kekerasan.

${ }^{43}$ Davit Setyawan, "KPAI: Agar Kasus Angeline Tak Terulang Sekolah Perlu Terlibat", http://www.kpai.go.id/berita/kpai-agar-kasus-angeline-tak-terulang-sekolah-perlu-terlibat/, diakses pada 19 November 2017.

${ }^{44}$ Arthur Rionaldi, Tinjauan Yuridis Terhadap Kekerasan, Op.Cit., hal. 13

${ }^{45}$ Tri Lestari Utami, Kekerasan Dalam Dunia Pendidikan, Op.Cit. 
Sekolah ada baiknya menyelenggarakan workshop pencegahan kekerasan di sekolah yang melibatkan seluruh siswanya. Workshop tersebut sebagai wadah guru dan siswa untuk berdiskusi mengenai kekerasan di sekolah seperti hukum yang terkait dengan kekerasan. Biarkan siswa memberikan pendapatnya dan minta mereka untuk membantu apabila ada temannya yang terlibat kekerasan di sekolah. Keterlibatan guru dan siswa ini diyakini mampu membantu siswa kembali ke perilaku yang normal.

5. Awasi tontonan anak.

Usahakan menghindarkan anak dari tayangan televisi atau film yang tidak mendidik, yang banyak mengandung unsur kekerasan, seperti tayangan film yang menampilkan tokoh superhero karena justru pada tayangan seperti ini sering ditemukan unsur kekerasan.

Upaya yang dilakukan oleh Komisi Perlindungan Anak terhadap kasus bullying dan tawuran agar tidak terjadi lagi disekolah adalah sebagai berikut :

1. Sekolah dan guru memiliki peran penting untuk mencegah terjadinya bullying atau perundungan di sekolah, penting untuk mendidik pola pikir antibullying kepada guru-guru di sekolah. penyelesaian bullying ini tidak selesai hanya dengan menurunkan regulasi. Kemendikbud seharusnya tidak hanya memberikan regulasi tapi tetapi juga memberikan persiapan kepada guru-guru atau orang tua untuk menghadapi bullying.

2. Orang tua juga memiliki peran untuk mengentaskan bullying lewat pendidikan parenting.

3. Melakukan sosialisasi terhadap efek dan dampak bullying dan harus diperhatikan adalah sikap pihak-pihak yang terlibat terhadap kekerasan yang terjadi di sekolah. Antara orang tua dan sekolah harus bisa menyikapi anak-anak agar tidak trauma dan balas dendam terhadp aksi bullying yang dirasakannya.

4. Langkah penyelesaian tindak pidana anak di luar pengadilan atau diversi adalah upaya yang baik dalam menyelesaikan kasus kekerasan. Melalui rehabilitasi menjadi efektif untuk memberikan pembinaan kepada anak serta memberikan hukuman yang edukatif.

5. Sekolah Ramah Anak menjadi upaya penyelesaian penghapusan kekerasan berbasis sekolah. Sekolah ramah anak merupakan model sekolah yang memastikan setiap anak secara inklusif berada dalam lingkungan yang aman, nyaman secara fisik, sosial, psikis dan dapat hidup tumbuh, berkembang dan berpartisipasi secara wajar sesuai fase perkembangannya. Serta mendapatkan perlindungan dari kekerasan dan diskriminasi. ${ }^{46}$

Upaya untuk memperkecil atau bahkan meniadakan tindak kekerasan di sekolah harus terus dilakukan, termasuk mengurangi kehadiran orang-orang yang mendukung dan menumbuh suburkan perilaku tersebut. Konsep sekolah yang ramah pada anak/ siswa merupakan hal yang sangat mendesak untuk diterapkan. Segenap stakeholder yang peduli dengan pendidikan dan pembentukan sikap mental atau akhlak peserta didik yang terpuji harus bersinergi untuk mewujudkan cita-cita mulia ini. National Education Association menjelaskan bahwa kasus bullying memberi dampak signifikan pada siswa dan keluarganya. Dalam penanganannya, kepala sekolah tidak hanya berinteraksi dengan pelaku maupun korban, namun juga harus bekerjasama dengan guru atau staf lain untuk mengurangi bullying. ${ }^{47}$

Upaya terakhir yang ditawarkan oleh KPAI yaitu sekolah ramah anak Area realisasi Sekolah Ramah Anak meliputi relasi sehari-hari, manajemen dan peraturan sekolah, sarana, prasarana dan lingkungan, kurikulum dan kebijakan. Relasi sehari-hari guru, murid, tenaga kependidikan, serta pihak lain di lingkungan sekolah adil dan setara. Manajemen sekolah dan peraturannya dibuat menggunakan perspektif perlindungan anak. Sarana dan prasarana sekolah serta lingkungannya diharapkan sesuai dengan keamanan dan kebutuhan anak. Begitu pula kurikulum dan kebijakannya, mengacu pada tujuan kepentingan terbaik bagi anak. Dalam hal ini sekolah menjadi tempat pencegahan sekaligus edukasi budaya yang ramah anak dalam bentuk perilaku dan kebiasaan-kebiasaan baik. Pembiasaan (habituasi) melalui edukasi budaya menyaratkan keaktifan orangtua, guru, karyawan, dan masyarakat dalam menggali nilai-nilai kearifan lokal. Dalam konsep empan papan, orangtua, guru, dan karyawan perlu memberi teladan yang baik bagi peserta didik. Guru akan menyebarkan salam (kedamaian) melalui tingkah laku keseharian yang terus memotivasi peserta didik untuk mampu berkomunikasi dengan sesamanya. Pola komunikasi dengan sesama peserta didik perlu diajarkan oleh guru, agar mereka mampu mengurai persoalan hubungan pertemanan dengan bijak. Saat mereka mampu berkomunikasi baik lisan dan bahasa tubuh (verbal maupun nonverbal), maka lingkungan sekolah akan dipenuhi oleh senyawa keakraban dan kekeluargaan yang mendorong semangat belajar dan meraih mimpi. Inilah pentingnya empan papan. Guru dapat memahami dan berkomunikasi dengan bahasa peserta didik. Yaitu bahasa yang mudah dimengerti sesuai dengan usia tumbuh kembang anak. Sekolah Ramah Anak dengan demikian, merupakan manifestasi cinta kasih sayang seluruh pemangku kepentingan pendidikan. Saat semua bertindak atas nama cinta, maka sekolah menjadi ruang dinamis yang menjadikan peserta didik betah berlama-lama berinteraksi

${ }^{46}$ Davit Setyawan, "KPAI Sekolah Berperan Penting Untuk Hentikan Bullying”, http://www.kpai.go.id/berita/kpai-nilaisekolah-berperan-penting-untuk-hentikan-bullying/, diakses pada 19 November 2017.

${ }^{47}$ Andi Halimah, et.al., "Persepsi Pada Bystander, Op.Cit. hal. 137. 
dengan guru, karyawan, teman, dan lingkungan sekitar. Semoga anak-anak dapat mendapatkan lingkungan yang menyenangkan di sekolah. ${ }^{48}$

\section{SIMPULAN}

Penyebab dari tindakan kekerasan yang dilakukan oleh guru disekolah adalah pertama guru dinilai kurang memiliki pengetahuan mengenai efek dari kekerasan itu sendiri, kedua cenderung memiliki persepsi yang parsial dalam menilai siswa, ketiga guru memiliki masalah psikologis yang membuatnya tidak mampu mengendalikan emosi, keempat adanya tekanan dalam pekerjaan, kelima pola pengajaran yang masih menganut otoritarian, keena, muatan kurikulum yang menekankan pada kemampuan kognitif dan cenderung mengabaikan kemampuan afektif.

Sedangkan penyebab dari tindakan kekerasan yang dilakukan sesama siswa berupa bullying dan tawuran yang kerap terjadi karena beberapa faktor yaitu pertama Faktor sosial anak, hal ini lebih kepada interaksi anak dengan teman sebaya nya yang biasa melakukan kekerasan, lantaran terbiasa ini anak menganggap bahwa kekerasan yang dilakukannya adalah wajar, kedua Faktor lingkungan, hal ini juga mempengaruhi anak untuk melakukan tindakan kekerasan terhadap teman sebayanya, seperti kebiasaan menggunakan gadget untuk melakukan permainan perangperangan, kemudian oleh anak dipraktekkan kepada teman sekelasnya, imbas dari film ataupun video game yang bersifat kekerasan. Lewat berbagai media tersebut, anak menjadi terbiasa dengan kekerasan, sehingga walaupun tidak melakukan kekerasan, dalam banyak kasus anak diketahuinya membiarkan terjadinya kekerasan, ketiga Faktor disfungsi keluarga, anak yang berasal dari latar belakang keluarga yang buruk memiliki potensi besar akan melakukan kekerasan. Keluarga yang tidak harmonis mempengaruhi psikologis anak secara bertahap, keempat Faktor Bullying yang dialami anak dilingkungan rumah/sekolah. Pengalaman buruk ini bisa berbentuk verbal atau psikis akan dilakukan oleh anak terhadap temannya atau bahkan orang lain.

Upaya penyelesaian kekerasan yang dilakukan oleh guru terhadap murid dapat dilakukan dengan hal berikut yaitu pertama menerapkan pendidikan tanpa kekerasan di sekolah, kedua mendorong/mengembangkan humaniasi pendidikan, ketiga hukuman yang di berikan berkolerasi dengan tindakan anak, keempat terus menerus membekali guru untuk menambah wawasan pengetahuan, kesempatan, pengalaman baru untuk mengembangkan kreativitas mereka, kelima bukan murid saja membutuhkan konseling, tapi juga guru. Sebab guru juga mengalami masa sulit yang membutuhkan dukungan, penguatan, atau bimbingan untuk menemukan jalan keluar yang terbaik.

Upaya penyelesaian kekerasan yang dilakukan oleh anak terhadap anak lain dalam hal ini bullying dan tawuran ada beberapa hal yang dapat dilakukan yaitu pertama Sekolah dan guru memiliki peran penting untuk mencegah terjadinya bullying atau perundungan di sekolah, penting untuk mendidik pola pikir anti bullying kepada guru-guru di sekolah, kedua orang tua juga memiliki peran untuk mengentaskan bullying lewat pendidikan parenting, ketiga melakukan sosialisasi terhadap efek dan dampak bullying, keempat langkah penyelesaian tindak pidana anak di luar pengadilan atau diversi adalah upaya yang baik dalam menyelesaikan kasus kekerasan, kelima Sekolah Ramah Anak menjadi upaya penyelesaian penghapusan kekerasan berbasis sekolah.

\section{Saran}

Terhadap kekerasan yang terjadi disekolah untuk pihak guru yang menjadi pelaku kekerasan, haruslah diberikan sosialisasi pendidikan tentang psikologi anak yang isinya tentang dampak dan efek kekerasan yang dilakukan kepada anak itu apa, kemudian mengajak para guru untuk mengubah mindset tentang memberi hukuman fisik kepada siswa adalah bentuk pendidikan moral. Karena hukuman fisik yang diberikan itu mengakibatkan terganggunya fisik dan mental serta psikologis anak. Jika tidak melakukan perubahan pola pikir ini, anak-anak akan cenderung untuk melakukan hal yang sama seperti apa yang dilakukan oleh guru kepada mereka, karena anak memiliki daya ingat dan daya rekam yang kuat atas apa yang terjadi kepadanya. Hal ini dapat menyebabkan timbulnya kekerasan yang juga dilakukan oleh anak kepada teman mereka. Untuk itu perlunya pengurangan tindakan kekerasan fisik yang dilakukan oleh guru disekolah terhadap anak dengan memberikan hukuman yang sifatnya mendidik bukan anarkis. Menjalankan kembali fungsi guru sebagai tenaga pendidik yang bermoral dan bertakwa kepada Tuhan Yang Maha Esa, sehingga apapun yang diajarkan kepada anak disekolah adalah atas dasar moral dan agama, karena peran guru disekolah adalah orangtua kedua dari siswa.

Terhadap anak yang telah mengalami kekerasan dari guru sebaiknya diberikan motivasi dan semangat terutama dari orangtua dirumah untuk mengajarkan anak berpikir positif tentang kekerasan yang telah terjadi kepadanya. Didikan orangtua merupakan peran penting untuk membangkitkan kembali semangat anak-anak yang mengalami kekerasan disekolah. Kemudian untuk anak yang melakukan tindakan kekerasan disekolah sebaiknya diberikan pendidikan moral yang khusus dengan tetap mengutamakan hak mereka sebagai anak. Tidak boleh memberikan hukuman keras kepada anak yang melakukan kekerasan ini, karena bisa menambah beban mental kepada

48 Davit Setyawan, "Sekolah Ramah Anak", http://www.kpai.go.id/artikel/sekolah-ramah-anak/, diakses pada 19 November 2017. 
anak sehingga bisa jadi mereka melakukan tindakan kekerasan lebih-lebih kepada guru bukan hanya siswa saja. Untuk itu saran yang diberikan oleh KPAI Sekolah Ramah Anak mengenai merupakan manifestasi cinta kasih sayang seluruh pemangku kepentingan pendidikan. Saat semua bertindak atas nama cinta, maka sekolah menjadi ruang dinamis yang menjadikan peserta didik betah berlama-lama berinteraksi dengan guru, karyawan, teman, dan lingkungan sekitar. Sehingga anak mendapat lingkungan yang menyenangkan di sekolah mereka.

\section{DAFTAR PUSTAKA \\ Buku-Buku}

Davidson, Scott, Hak Asasi Manusia, Sejarah, Teori dan Praktek dalam Pergaulan Internasional. Jakarta: Grafiti, 1994.

Eddyono, Supriyadi W., Pengantar Konvensi Hak Anak. Jakarta: ELSAM, 2005.

Joni, Muhammad, Hak-Hak Anak dalam UU Perlindungan Anak dan Konvensi PBB tentang Hak Anak: Beberapa Isu Hukum Keluarga. Jakarta: KPAI, t.t.

Lubis, Todung Mulya, In search of Human Rights Legal-Political Dilemmas of Indonesia's New Order. Jakarta: Gramedia, 1993.

Palguna, Dewa Gede, Pengaduan Konstitusional (Constitusional Complain). Jakarta: Sinar Grafika.

Prints, Darwan, Hukum Anak Indonesia. Bandung: PT. Citra Aditya Bakti, 2003.

Smith, Rhona K. M., et. al., Hukum Hak Asasi Manusia. Yogyakarta: PUSHAM-UII, 2008.

Soekanto, Soerjono dan Sri Mamudji, Penelitian Hukum Normatif Suatu Tinjauan Singkat. Jakarta: Rajawali Press, 2003.

Waluyo, Bambang, Penelitian Hukum Dalam Praktek. Jakarta: Sinar Grafika, 2002.

\section{Peraturan Perundang-undangan}

Indonesia, Undang Undang Dasar Negara Republik Indonesia Tahun 1945 Amandemen ke IV.

Indonesia, Undang Undang Dasar Negara Republik Indonesia Tahun 1945 Amandemen ke II.

Indonesia, Undang Undang Perlindungan Anak, UU No. 35 Tahun 2014, LN No. 297 Tahun 2014, TLN No. 5606.

\section{Jurnal Ilmiah}

Fataruba, Rina, "Peran Tekanan Teman Sebaya Terhadap Perilaku Bullying pada Remaja di Sekolah", Seminar ASEAN Kedua Psychology dan Humanity, Psychology Forum UMM, (19-20 Februari 2016), hal. 356.

Halimah, Andi, et.al., "Persepsi Pada Bystander Terhadap Intensitas Bullying pada Siswa SMP”, Jurnal Psikologi Volume 42, No. 2 (Agustus 2015), hal. 129-140.

Octalina, Benedhicta Desca Prita. "Perlindungan Hukum Terhadap Anak Korban Eksploitasi Ekonomi”, Jurnal Skripsi Peradilan dan Penyelesaian Sengketa Hukum, (2014).

Rionaldi, Arthur, Tinjauan Yuridis Terhadap Kekerasan Yang Dilakukan Oknum Guru Terhadap Murid Di Sekolah, Jurnal Ilmu Hukum, (2014), hal. 4.

Utami, Tri Lestari, Kekerasan Dalam Dunia Pendidikan, Jurnal Ilmu Pendidikan, (2014), hal. 1.

\section{Skripsi}

Irawan, Siti Hajar Rezki, "Pemenuhan Hak Konstitusional Terhadap Fakir Miskin dan Anak Terlantar Dalam Bidang Pendidikan Di Kota Makassar", Skripsi Universitas Hasanuddin, Makassar, 2013.

Lestari, Pipin, Hak Konstitusional Pemenuhan Pendidikan Di Daerah Pendudukan, Skripsi Universitas Lampung, 2016.

\section{Surat Kabar Harian}

Fauza, Rahmatul. "Video Guru Pukul Siswa, Begini Kata Dinas Pendidikan Pangkal Pinang", Kompas, (6 November 2017).

Hartik, Andi. "84 Persen Siswa Indonesia Alami Kekerasan di Sekolah”, Kompas, (29 November 2016).

Nadlir, Moh. "Video Kekerasan terhadap Siswa, Pelaku Diduga Orangtua Siswa", Kompas, (6 November 2017).

Purwadi, Didi. "Riset : 30 Juta Anak Indonesia Pengguna Gadget", Republika, (18 Februari 2014).

Putra, Andri Donal. "KPAI: Pelaku Kekerasan dan "Bullying" di Sekolah Tahun 2015 Meningkat", Kompas, (30 Desember 2015).

\section{Internet}

Hendrian, Dedi. "Banyak Alasan Remaja Melakukan Kekerasan", http://www.kpai.go.id/berita/kpai-banyak-alasanremaja-lakukan-kekerasan/, diakses pada 19 November 2017. 
Ibu dan Mama, "Kekerasan Yang Terjadi di Sekolah",http://www.ibudanmama.com/pola-asuh/kekerasan-yangterjadi-di-sekolah/, kekerasan yang terjadi di sekolah, diakses tanggal 15 November 2017.

Komisi Perlindungan Anak Indonesia, "Rincian Data Kasus Berdasarkan Klaster tahun 2011-2016", http://bankdata.kpai.go.id/tabulasi-data/data-kasus-per-tahun/rincian-data-kasus-berdasarkan-klasterperlindungan-anak-2011-2016, diakese pada 15 November 2017.

Setyawan, Davit. "KPAI Sekolah Berperan Penting Untuk Hentikan Bullying", http://www.kpai.go.id/berita/kpainilai-sekolah-berperan-penting-untuk-hentikan-bullying/, diakses pada 19 November 2017.

Setyawan, Davit. "KPAI: Agar Kasus Angeline Tak Terulang Sekolah Perlu Terlibat", http://www.kpai.go.id/berita/kpai-agar-kasus-angeline-tak-terulang-sekolah-perlu-terlibat/, diakses pada 19 November 2017.

Setyawan, Davit. "Sekolah Ramah Anak", http://www.kpai.go.id/artikel/sekolah-ramah-anak/, diakses pada 19 November 2017. 